\title{
CHARACTERIZATION OF Urochloa humidicola METHANOL EXTRACT AS A PHYTOGENIC ADDITIVE FOR RUMINANTS
}

\section{CARACTERIZAÇÃO DO EXTRATO METANÓLICO DE Urochloa humidicola COMO ADITIVO FITOGÊNICO PARA RUMINANTES}

\author{
Rafaela Scalise Xavier de FREITAS ${ }^{1}$; Delci de Deus NEPOMUCENO ${ }^{2}$; \\ Elisa Cristina MODESTO ${ }^{\mathbf{3}}$; Débora Ramos de OLIVEIRA ${ }^{\mathbf{4}}$; Tatiana Pires PEREIRA ${ }^{\mathbf{1}}$; \\ Leonardo Fiusa de MORAIS ${ }^{1}$; João Carlos de Carvalho ALMEIDA ${ }^{3}$; \\ Mário Geraldo de CARVALHO
}

1. Zootecnista, Discente do Programa de Pós-Graduação em Zootecnia da UFRRJ (PPGZ/UFRRJ), rafascalise@ @otmail.com; 2. Médico veterinário, Pós-Doutorando no PPGZ/UFRRJ, Bolsista PNPD/CAPES; 3. Zootecnista, Professor do Instituto de Zootecnia da UFRRJ;

4. Química, Discente do curso de Pós-Graduação em Química da UFRRJ (PPGQ/UFRRJ); 5. Químico, Professor do Instituto de Ciências Exatas da UFRRJ (ICE/UFRRJ).

\begin{abstract}
This survey aimed to characterize a Urochloa humidicola methanol extract regarding the presence of secondary metabolites classes and to determine its bromatological composition. $U$. humidicola samples were dried under shade, milled on a 2-mm sieve by a Willey mill. The solution obtained was filtered using filter paper and concentrated in a rotary evaporator under reduced pressure; the concentrated residue was then placed in an open vessel to complete solvent removal using continuous air flow dryers. Phytochemical prospection tests and bromatological composition analyses were performed on the dry methanol extract, and the results were compared to in natura $U$. humidicola. The methanol extract had $10.2 \% \mathrm{CP}$ and $35 \% \mathrm{EE}$ and in natura U. humidicola had $5.17 \% \mathrm{CP}$ and $1.57 \% \mathrm{EE}$, with a difference $(\mathrm{P}<0.05)$ of $5 \%$ by Fisher's test. In natura U. humidicola had 75.59\% NDF, 40.77\% ADF, 38.82\% HEM, $29.93 \%$ CEL, and 7.19\% LIG. Methanol extraction by cold maceration reduced the LIG $(0.17 \%)$ and CEL $(0.21 \%)$ contents as only soluble constituents were extracted. A phytochemical assay was positive for the presence of saponins, tannins, alkaloids, non-protein amino acids, carbohydrates, cardiac glycosides, steroids, tripernoids, catechins, and saccharides and was negative for the presence of flavonoids and purines. The $U$. humidicola methanol extract possesses traits that allow its use as a phytogenic and natural additive.
\end{abstract}

KEYWORDS: Plant extract. Secondary metabolites. Nutrition.

\section{INTRODUCTION}

World population growth has resulted in more food production and a greater demand for agricultural products (WANAPAT et al., 2013). Responding to international and national demands, Brazilian livestock has been targeted for investments in production development, as well as in biotechnology, to consolidate Brazil as the main exporter of meat products; this caused an increase in tests on natural products for use in animal feed, such as nutraceutical food or phytogenic additives.

Secondary metabolites are present in plant extracts in large amounts and possess several functions including chemical defense (SLIWINSKI et al., 2002). Some metabolites have specific functions such as protection against herbaria and infection by pathogenic microorganisms (NEPOMUCENO et al., 2013) and have antimicrobial traits, thus allowing their application as ruminal fermentation inducers by the selective inhibition of ruminal microorganisms (KAMRA et al., 2006) and consequent mitigation of methane production (SANTRA et al., 2012).
According to Wanapat et al. (2013), plant extracts with condensed tannins and saponins have been used as additives in ruminant feed in contrast to ionophores for the mitigation of methane production.

Plant extracts from garlic (Allium sativum), pepper (Capsicum annuum), cinnamon (Cinnamomum cassia), oregano (Origanum vulgare), and fennel (Pimpinella anisum) have been used as in vitro ruminal fermentation inducers in beef cattle feed with a high-concentrate quantity (CARDOZO et al., 2005); on the other hand, when used in human feed, some conflicts might exist related to the increase in product prices.

Forage legumes and grass have active components such as saponins, tannins, and phenolic compounds (SIROHI et al., 2014), allowing the use of the forage itself as a method for modifying ruminal fermentation. $U$. humidicola contains saponins that allow its application in ruminant feed to transform fermentative patterns.

The present study evaluated $U$. humidicola methanol extract production and characterization to 
study its chemical-bromatological composition and secondary metabolite classes.

\section{MATERIAL AND METHODS}

The experiment was performed at the Animal Science Institute in UFRRJ, Seropédica, Rio

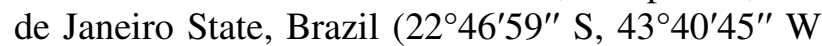
and $33 \mathrm{~m}$ altitude). Experimental soil was classified as Haplic Planosol (EMBRAPA, 1999). The region climate was classified as Aw according to Köppen.

$U$. humidicola samples were harvested from the section $0.05 \mathrm{~m}$ above the soil surface, in particular, in October 2013. The sample was dried under shade for 7 days and was subsequently milled on a 2-mm sieve by a Willey mill (Tecnal TE 680 model). A portion of the sample was stored in glass flasks containing methanol. The solution obtained was filtered through filter paper and concentrated under reduced pressure using a rotary evaporator. The concentrated residue was placed on an open container for solvent removal by employing continuous air flux dryers.

The $U$. humidicola crude methanol extract (UhME) was subjected to several chemical reactions for the detection of saponins, tannins, alkaloids, flavonoids, non-protein amino acids, carbohydrates, cardiac glycosides, saccharides, steroids, tripernoids, catechins, and purines (BARBOSA FILHO, 2001; MATOS, 1998).

In natura $U$. humidicola and the $U$. humidicola crude methanol extract were subjected to bromatological analysis for determining the dry matter (DM), crude protein (CP), mineral matter $(\mathrm{MM})$, and ether extract (EE) contents, according to methods 934.01, 984.13, 924.05, and 960.39, respectively (AOAC, 1990). The non-fibrous carbohydrate (NFC) content was determined according to the following equation, NFC content $=$ $100-(\% \mathrm{NDF}+\% \mathrm{CP}+\% \mathrm{EE}+\% \mathrm{MM})$, described in NRC (2001); the neutral detergent fiber (NDF), acid detergent fiber (ADF), lignin (LIG), and cellulose (CEL) contents were determined according to the method by Van Soest et al. (1991), and the hemicellulose (HEM) content was determined as the difference between the NDF and ADF contents. The determination of the EE content from the $U$. humidicola crude methanol extract was performed according to the methodology by Bligh \& Dyer (1959), where chloroform, methanol, distilled water, and $1.5 \% \mathrm{Na}_{2} \mathrm{SO}_{4}$ were used at ratios of 1:1:0.8:0.5, respectively. The $U$. humidicola samples were harvested from three different plots located at UFRRJ goats research facility; each sample was divided into two subsamples: one for performing bromatological analysis and another for obtaining the crude methanol extract. The crude methanol extract was sampled during bromatological analyses, and the results were compared with those of in natura $U$. humidicola.

The results of bromatological analyses were subjected to ANOVA by comparing averages by Fisher's test using the 9.1 Saeg software (UFV, 2007). The results of the phytochemical prospecting tests were characterized as in terms of the intensity of the presence of each class of metabolites and represented via the cross system, where $(+++)$ denotes a large presence, $(++)$ denotes a considerable presence, $(+)$ denotes a moderate presence, and (0) denotes no presence or inconclusive presence for each secondary metabolite class, the result was the average number of crosses given by two evaluators for each repetition of the extracts.

\section{RESULTS AND DISCUSSION}

There was a significant difference $(\mathrm{P}<0.05)$ between the CP, EE, MM, and NFC contents, in the $U$. humidicola extract that showed higher values than those in in natura $U$. humidicola. For the NDF, ADF, HEM, CEL, and LIG contents, in natura U. humidicola had higher values than the $U$. humidicola extract (Table $1)$.

The $U$. humidicola extract had $5.17 \% \mathrm{CP}$, which was lower than the values of $11.74 \%$ and $7.89 \%$ reported by Pereira et al. (2011) from cuts performed in two periods: December 2006 to March 2007 and November 2007 to March 2008 at Alto Vale do Jequitinhonha, Minas Gerais, Brazil.

The difference in protein content might be related to the time of the year (cutting performed in October) and plant phenological period (four months following the last grazing period), in addition to soil traits and the absence of fertilization. The $U$. humidicola methanol extract protein content $(10.2 \%)$ and the EE content $(35 \%)$ were higher than those in in natura $U$. humidicola $(\mathrm{P}<0.05)$. Thus, the increase of these constituents might be explained by the extraction method which carries out only the methanol soluble constituents, due to the LIG, CEL, and hemicellulose constituents are not solubilized by methanol.

In natura $U$. humidicola and the $U$. humidicola methanol extract had $9.59 \%$ and $39.92 \%$ NFCs, respectively $(\mathrm{P}<0.05)$. NFCs are represented by fractions (soluble sugars, pectin, and starch) that are soluble in water (OLIVEIRA et al., 2016). Using methanol as the solvent, NFC fractions were concentrated in the $U$. humidicola extract. 
Table 1. Chemical-bromatological composition of Urochloa humidicola and the U. humidicola methanol extract (UhME) based on dry matter

\begin{tabular}{cccc}
\hline Constituents & U. humidicola & UhME & CV \% \\
\hline DM \% & $89.36 \mathrm{~A}$ & $81.42 \mathrm{~B}$ & 0.66 \\
CP & $5.17 \mathrm{~B}$ & $10.20 \mathrm{~A}$ & 3.86 \\
EE & $1.57 \mathrm{~B}$ & $35.00 \mathrm{~A}$ & 1.18 \\
MM & $8.14 \mathrm{~B}$ & $16.14 \mathrm{~A}$ & 4.51 \\
NFC & $9.59 \mathrm{~B}$ & $39.92 \mathrm{~A}$ & 7.20 \\
NDF & $75.59 \mathrm{~A}$ & $0.14 \mathrm{~B}$ & 3.11 \\
ADF & $40.77 \mathrm{~A}$ & $0.18 \mathrm{~B}$ & 1.23 \\
HEM & $34.82 \mathrm{~A}$ & $0.00 \mathrm{~B}$ & 5.38 \\
CEL & $29.73 \mathrm{~A}$ & $0.21 \mathrm{~B}$ & 0.63 \\
LIG & $7.19 \mathrm{~A}$ & $0.17 \mathrm{~B}$ & 2.19 \\
\hline
\end{tabular}

DM: dry matter, CP: crude protein, EE: ether extract, MM: mineral matter, NFC: non-fibrous carbohydrate, NDF: neutral detergent fiber, ADF: acid detergent fiber, HEM: hemicellulose, CEL: cellulose, LIG: lignin. CV: coefficient of variation. Values followed by different letters in the same column differ by $5 \%$ according to Fisher's test $(\mathrm{P}<0.05)$.

NDF, ADF, and LIG contents were $75.59 \%$, $40.77 \%$, and $7.19 \%$, respectively, which were in contrast to the values reported by Pereira et al. (2011), which were $68.10 \%, 43.91 \%$, and $5.10 \%$, respectively. In natura $U$. humidicola had $34.82 \%$ and $29.73 \%$ HEM and CEL, respectively. This difference may have occurred due to the time when forage cutting was done as the work by Pereira et al. (2011) was performed during the rainy season with 42-day-old plants, with the correction of soil $\mathrm{pH}$ in the experimental area with limestone and fertilization with nitrogen and phosphate sources, which did not occur in the present study.

LIG $(0.17 \%)$ and CEL $(0.21 \%)$ contents in the methanol extract were low due to cold maceration by methanol extracting soluble constituents such as proteins, lipids, and MM.

The phytochemical prospection qualitative assays provided general information on the $U$. humidicola chemical profile and presented several metabolites classes; however, no presence of flavonoids and purines was reported (Table 2).

Table 2. Phytochemical prospection qualitative assays of the $U$. humidicola methanol extract

\begin{tabular}{cc}
\hline Secondary Metabolite Classes & Results \\
\hline Saponins & +++ \\
Tannins & +++ \\
Alkaloids & +++ \\
Flavonoids & 0 \\
Non-protein amino acids & +++ \\
Carbohydrates & +++ \\
Cardiac glycosides & +++ \\
Steroids and terpenoids & +++ \\
Catechins & +++ \\
Saccharides & +++ \\
Purines & 0 \\
\hline
\end{tabular}

$(+++)$ large presence and (0) no presence or inconclusive presence

Phytochemical prospection has lower accuracy than other identification methods such as chromatographic analysis; phytochemical prospection might interfere with the interpretation of some results due to staining (GRANATO et al., 2013) as it provides an overview of the various classes of chemical constituents that may be present in the plant analyzed. However, the same authors addressed the importance of performing these tests as a mechanism to direct the fractionation of crude extracts and to identify active components to allow biological assays to be performed. This was corroborated by Bessa et al. (2013) who mentioned that this easy to perform, fast, and inexpensive technique is important in preliminary studies on plants considering that the phytochemical profile is still not widely studied.

Age and plant development may influence the presence and amount of metabolites (GOBBONETO; LOPES, 2007). Brum et al. (2009) observed high protodioscin levels in $U$. decumbens and $U$. brizantha at the maturation period. In animal nutrition, secondary metabolites such as tannins and saponins are generally mentioned in the literature 
because of their action on ruminal a microorganism, it may justify the use of plant extracts containing them as inducers of ruminal fermentation in order to optimize the use of nutrients in foods (TADESSE 2014; WENCELOVÁ et al., 2014). To promote an increase in the performance of animals and reduce the negative effects on the environment, there should be a greater use of food energy and lower production of ruminal methane (ANANTOSOOK et al., 2014).

Alkaloids act on ruminal microbiota and promote improvement in ruminal fermentation patterns and the better use of nitrogenous constituents of food when present in cattle diets (AGUILAR-HERNANDEZ et al., 2016). To date, other secondary metabolites such as non-protein amino acids, carbohydrates, cardiac glycosides, steroids, terpenoids, catechins, and saccharides have not been mentioned as promoters of ruminal fermentation by the modification of ruminal microbiota to promote increased animal performance. However, cardiac glycosides, steroids, and terpenoids bring about negative effects when present in animal diets (NEPOMUCENO et al., 2013).

\section{CONCLUSION}

The $U$. humidicola methanol extract possesses traits that allow its use as a phytogenic or natural additive for inducing ruminal fermentation.

RESUMO: Objetivou-se neste estudo caracterizar o extrato metanólico de Urochloa humidicola, quanto à presença de classes de metabólitos secundários presentes bem como determinar a sua composição bromatológica. Para isto, amostras da parte aérea de $U$. humidicola foram secas à sombra, moídas em moinho tipo Willey em partículas de 2 $\mathrm{mm}$, submetidas à extração por maceração a frio com metanol, a solução obtida foi concentrada em rotaevaporador e posto para termina a secagem sob fluxo de ar contínuo. O extrato metanólico seco foi submetido aos testes de prospecção fitoquímica e análises de composição bromatológica comparado com a $U$. humidicola in natura. $\mathrm{O}$ extrato apresentou $10,2 \%$ de PB e $35 \%$ de EE e $U$. humidicola in natura apresentou 5,17\% de PB e 1,57\% de EE, diferindo entre si $(\mathrm{P}<0,05)$ pelo teste de Fisher a 5\% de significância. A U. humidicola in natura apresentou teores de FDN (75,59\%), FDA (40,77\%), hemicelulose $(38,82 \%)$, celulose $(29,93 \%)$ e lignina $(7,19 \%)$. O método de extração por maceração a frio com metanol contribuiu para a diminuição dos teores de lignina $(0,17 \%)$ e celulose $(0,21 \%)$, por extrair somente os constituintes solúveis. O ensaio fitoquímico apresentou presença positiva para saponina, tanino, alcaloides, aminoácidos não proteicos, carboidratos, glicosídeos cardioativos, esteroides e tripernoides, catequinas e sacarídeos, e negativa para a presença de flavonoides e purinas. O extrato metanólico de Urochloa humidicola apresenta características que permitem seu uso como aditivo natural ou fitogênico.

PALAVRAS-CHAVE: Extrato de plantas. Metabólitos secundários. Nutrição.

\section{REFERENCES}

AGUILAR-HERNÁNDEZ, J. A.; URÍAS-ESTRADA, J. D.; LÓPEZ-SOTO, M. A.; BARRERAS, A.; PLASCENCIA, A.; MONTAÑO, M.; GONZÁLEZ-VIZCARRA,V. M.; ESTRADA-ANGULO, A.; CASTROPÉREZ, B. I.; BARAJAS, R.; ROGGE, H. I.; ZINN, R. A. Evaluation of isoquinoline alkaloid supplementation levels on ruminal fermentation, characteristics of digestion, and microbial protein synthesis in steers fed a highenergy diet. Journal of Animal Science, Champaign, v. 94, n. 1, p. 267-274, jan. 2016. https://doi.org/10.2527/jas.2015-9376

ANANTASOOK, N.; WANAPAT, M.; CHERDTHONG, A. Manipulation of ruminal fermentation and methane production by supplementation of rain tree pod meal containing tannins and saponins in growing dairy steers. Journal of Animal Physiology and Animal Nutrition, Berlim, v. 98, n. 1, p. 50-55, dec. 2014. https://doi.org/10.1111/jpn.12029

AOAC-Association of Official Analytical Chemists. Official methods of analysis. 15th ed. Arlington: AOAC International, 1990.

BARBOSA FILHO, J. M. Triagem fitoquímica. João Pessoa: Departamento de Ciências Farmacêuticas. Universidade Federal da Paraíba. 10p, 2001. 
BESSA, N. G. F.; BORGES, J. C. M.; BESERRA, F. P.; CARVALHO, R. H. A.; PEREIRA, M. A. B.; FAGUNDES, R.; CAMPOS, S. L.; RIBEIRO, L. U.; QUIRINO, M. S.; CHAGAS JUNIOR, A. F.; ALVES, A. Prospecção fitoquímica preliminar de plantas nativas do cerrado de uso popular medicinal pela comunidade rural do assentamento vale verde - Tocantins. Revista Brasileira de Plantas Medicinais, Campinas, v. 15, n. 4, supl. I, p. 692-707, aug. 2013.

BLIGH, E. G.; DYER, W. J. A rapid method of total lipid extraction and purification. Canadian Journal Biochemistry Physiology, Ottawa, v. 37, n. 8, p. 911-917, aug. 1959. https://doi.org/10.1139/o59-099

BRUM, K. B.; HARAGUCHI, M.; GARUTTI, M. B.; NÓBREGA, F. N.; ROSA,B.; FIORAVANTI, M. C. S. Steroidal saponin concentrations in Brachiaria decumbens and B. brizantha at different developmental stages. Ciência Rural, Santa Maria, v. 39, n. 1, p. 279-281, jan./ feb. 2009.

CARDOZO, P. W.; CALSAMIGLIA, S.; FERRET, A.; KAMEL, C. Screening for the effects of natural plant extracts at different $\mathrm{pH}$ on in vitro rumen microbial fermentation of high concentration of a high-concentrate diet for beef cattle. Journal of Animal Science, Champaign, v. 83, n. 11, p. 2572-2579, nov. 2005. https://doi.org/10.2527/2005.83112572x

GOBBO-NETO, L.; LOPES, P. N. Plantas medicinais: fatores de influência no conteúdo do metabolismo secundários. Química Nova, São Paulo, v. 30, n. 2, p. 374-381, apr. 2007. https://doi.org/10.1590/S010040422007000200026

GRANATO, E. M.; GRANATO, M. M.; GERENUTTI, M.; SILVA, M. G.; FERRAZ, H. O.; VILA, M. M. D. C. Prospecção fitoquimica da espécie vegetal Trixis antimenorrhoea (Schrank) Kuntze. Revista Brasileira Farmácia, Rio de Janeiro, v. 94, n. 2, p. 130-135, mar. 2013.

KAMRA, D. N.; AGARWAL, N. and CHAUDHARY, L. C. Inhibition of ruminal methanogenesis by tropical plants containing secondary compounds. International Congress Series, Amsterdam, v. 1293, n. 1, p. 156163 , july 2006.

MATOS, F. J. A. Introdução a fitoquímica experimental. Fortaleza: Edições UFC, 124p, 1988.

MEDEIROS, S. R.; GOMES, R. C.; BUNGENSTAB, D. J. Nutrição de bovinos de corte: fundamentos e aplicações. Brasília, DF: Embrapa, 176 p., 2015.

National Research Council. Nutrient requirements of dairy cattle. NRC. 7 ed. (Washington, D.C.: National Academic Press), 381 p, 2001.

NEPOMUCENO, D. D.; ALMEIDA, J. C. C.; CARVALHO, M. G.; FERNANDES, R. D. and CATUNDA JÚNIOR, F. E. A. Classes of secondary metabolites identified in three legume species. Braz. Revista Brasileira de Zootecnia, Viçosa, v. 42, n. 10, p. 700-705, oct. 2013.

OLIVEIRA, V. S.; SANTANA NETO, J. A.; VALENÇA, R. L.; SILVA, B. C. D.; SANTOS, A. C. P. Carboidratos fibrosos e não fibrosos na dieta de ruminantes e seus efeitos sobre a microbiota ruminal. Veterinária Noticias, Uberlândia, v. 22, n. 2, p. 1-18, july/dec. 2016.

PEREIRA, R. C.; RIBEIRO, K. G.; PEREIRA, G. O.;SILVA, J. L.; SANTOS, J. M.; RIGUEIRA, J. P. S. Produtividade e composição bromatológica de Brachiaria spp., no Alto Vale do Jequitinhonha. Ciência Agrotecnologia, Lavras, v. 35, n. 3, p. 524-530, may 2011.

Saeg - Sistema para Análises Estatísticas. versão 9.1: Fundação Arthur Bernardes - UFV - Viçosa, 2007.

SANTRA, A.; SAIKIA, A.; BARUAH, K. K. Scope of rumen manipulation using medicinal plants to mitigate methane production. Journal of Pharmacognosy, Bangalore, v. 3, n. 2, p. 115-120, apr. 2012. 
SIROHI, S. K.; GOEL, N.; SINGH, N. Utilization of saponins, a plant secondary metabolite in enteric methane mitigation and rumen modulation. Annual Research \& Review Biology, San Antonio, v. 4, n. 1, p. 1-19, oct. 2014. https://doi.org/10.9734/ARRB/2014/5323

SLIWINSK, B. J.; SOLIVA, C. R.; MACHUMULLER, A.; KREUZER, M. Efficacy of plant extracts rich in secondary constituents to modify rumen fermentation. Animal Feed Science and Technology, Amsterdam, v. 101, n. 1-4, p. 101-114, apr. 2002. https://doi.org/10.1016/S0377-8401(02)00139-6

TADESSE, G. Rumen manipulation for enhanced feed utilization and improved productivity performance of ruminants: a review. Momona Ethiopian Journal of Science, Mekelle, v. 6, n. 2, p. 3-17, 2014.

VAN SOEST, P. J.; ROBERTSON, J. B.; LEWIS, B. A. Methods for dietary fiber, neutral detergent fiber and non-starch polysaccharides in relation to animal nutrition. Journal of Dairy Science, Champaign, v. 74, n. 10, p. 3583-3597, oct. 1991. https://doi.org/10.3168/jds.S0022-0302(91)78551-2

WANAPAT, M.; KANG, S.; POLYORACH, S. Development of feeding systems and strategies of supplementation to enhance rumen fermentation and ruminant production in the tropics. Journal of Animal Science and Biotechnology, Amsterdam, v. 4, n. 32, p. 1-11, aug. 2013. https://doi.org/10.1186/2049-1891-432

WENCELOVÁ, M.; VÁRADYOVÁ, Z.; MIHALIKOVÁ, K.; JALČ, D.; KIŠIDAYOVÁ, S. Effects of selected medicinal plants on rumen fermentation in a high-concentrate diet in vitro. The Journal of Animal \& Plant Sciences, Lahore v. 24, n. 5, p. 1388-1395, oct. 2014. 